\title{
Adenosine Receptor A3
}

National Cancer Institute

\section{Source}

National Cancer Institute. Adenosine Receptor A3. NCI Thesaurus. Code C38616.

Adenosine receptor A3 (318 aa, $\sim 36 \mathrm{kDa}$ ) is encoded by the human ADORA3 gene. This protein plays a role in G protein-coupled receptor signaling. 